\title{
Ishikawa cells exhibit differential gene expression profiles in response to oestradiol or 4-hydroxytamoxifen
}

\author{
Suzanne M Johnson, Manijeh Maleki-Dizaji, Jerry A Styles and lan N H White
}

MRC Molecular Endocrinology Group, Reproductive Sciences Section, Department of Cancer Studies and Molecular Medicine, University of Leicester, Leicester LE2 7LX, UK

(Requests for offprints should be addressed to S M Johnson; Email: smj4@le.ac.uk)

\begin{abstract}
In this study, the oestrogen agonist/antagonist action of 4-hydroxytamoxifen $\left(\mathrm{OHT} ; 1 \times 10^{-6} \mathrm{M}\right)$ and $17 \beta$-oestradiol $\left(\mathrm{E}_{2} ; 1 \times 10^{-8} \mathrm{M}\right)$ were assessed on the oestrogen receptor $(\mathrm{ER})$-positive epithelial cell line (Ishikawa) with respect to cell proliferation, and to gene and protein expression. QRT-PCR and western blotting confirmed that Ishikawa cells expressed both ER isoforms and that there was no change in transcript levels in response to either ligand. Gene expression profiles, using oligonucleotide arrays representing $\sim 19000$ human genes, showed that the expression of 716 and 534 genes were changed differentially by treatment with either $\mathrm{OHT}$ or $\mathrm{E}_{2}$ respectively, at the 24-h time point, with modulation of 46 genes common to both ligands, whereas $335(O H T)$ and $240\left(E_{2}\right)$ genes showed expression changes unique to ligand, with 13 common alterations at $48 \mathrm{~h}$. Both $\mathrm{OHT}$ and $\mathrm{E}_{2}$ had demonstrable oestrogen agonist actions on Ishikawa cells, exemplified by increased proliferation and expression of known oestrogen-responsive genes, such as creatine kinase $B$ and by the induction of alkaline phosphatase activity. Additionally, the data indicate that the two oestrogen agonists generated not only common gene expression changes but also unique ligand-specific profiles, raising the intriguing possibility that tamoxifen has $\mathrm{E}_{2}$-independent effects on the uterine epithelium.
\end{abstract}

Endocrine-Related Cancer (2007) 14 337-350

\section{Introduction}

Tamoxifen has been the leading adjuvant breast cancer treatment for more than two decades. It is licensed as a chemopreventive agent in the US following findings of a $49 \%$ reduction in invasive breast cancer in treated women (Fisher et al. 1998) and has proven to be an extremely effective treatment for oestrogen receptor (ER)-positive breast cancer; however, it is not without adverse side effects.

Epidemiological evidence has shown that tamoxifen treatment confers a two- to sevenfold increased risk of developing endometrial pathologies (Cohen et al. 1993, McGonigle et al. 2006), including endometrial cancer (Fisher et al. 1998, Cohen 2004). Type 1 endometrial tumours are associated with a history of unopposed oestrogen exposure (Amant et al. 2005) and the aberrant proliferation of the endometrium in post-menopausal women receiving tamoxifen treatment could be due to the oestrogen-like agonistic action of tamoxifen in this tissue (White 2001). In this context, the role of tamoxifen in terms of carcinogenesis is considered to be that of a tumour promoter, whereby the accumulation of genetic insults increases the likelihood of damage occurring in critical genes involved in or leading to a proliferative response in the endometrial epithelial cell.

In recent years, some of the molecular genetic alterations associated with both Type I and Type II endometrial carcinomas have been elucidated and include mutations in PTEN, K-RAS, TP53, CTNNB1 ( $\beta$-catenin), and the presence of microsatellite instability (MI), a marker of inactivation of DNA mismatch repair (Prasad et al. 2005). As atypical hyperplasia is the precursor lesion in endometrioid carcinoma Type 1 (Levine et al. 1998), elucidation of the non-genotoxic effect of tamoxifen, particularly with respect to uterine endometrial cell proliferation, would be highly informative.

Although the tissue-specific activity of tamoxifen has been well documented (Lonard \& Smith 2002, Shang \& Brown 2002), the molecular mechanisms 
remain unclear. Tamoxifen binds to and activates, both ER isoforms ( $\alpha$ and $\beta$ ) in a tissue-specific manner (Watanabe et al. 1997) and its ability to exert a tissuespecific agonist/antagonist effect led to its classification as the prototypic selective ER modulator (SERM; Cole et al. 1971, Ward 1973). Transcriptional activation of oestrogen-regulated genes is thought to occur through the association of the ligand-bound ER directly with oestrogen response elements (EREs) in the promoter region of target genes (McDonnell \& Norris 2002), or indirectly through interaction with other transcription factor complexes such as AP1 or SP1 (Kushner et al. 2000, Shang \& Brown 2002). However, the efficacy of the activated ER is influenced further by post-translational modifications, such as site-specific phosphorylation or ubiquitination (Shang 2006). Several in vitro studies have shown that oestradiol $\left(\mathrm{E}_{2}\right)$ and related SERMs differentially regulate target gene expression via $\mathrm{ER} \alpha$ or $\mathrm{ER} \beta$ (Kian et al. 2004, Stossi et al. 2004, Monroe et al. 2005). Recently, it has been demonstrated, in various human cell types, that interaction between growth factor receptors and a membrane-associated ER $\alpha$ isoform (Kato 2001) leads to rapid non-genomic signalling through cytoplasmic phosphorylation cascades (Pedram et al. 2002, Song \& Santen 2006). Genomic activation of transcription by ligand-bound $\mathrm{ER}$ is influenced further by the recruitment of co-regulator proteins in a promoter-specific manner (Klinge et al. 2004). The expression of proteins such as nuclear receptor interacting protein (NRIP) and nuclear receptor co-repressor $2 /$ silencing mediator for retinoid and thyroid hormone receptors (SMRT) have been shown to be cell-type specific (Shang \& Brown 2002) and may add to the selective regulation of ER transcriptional activity by tamoxifen (Smith et al. 1997, Keeton \& Brown 2005). Each of these cellspecific mechanisms could play a critical role in the transcriptional behaviour of a target cell in response to SERMs, by potentially modulating the agonist/ antagonist effect of each compound.

To assist the search for a SERM that acts as an oestrogen antagonist in the breast, but shows minimal agonistic action in the uterus, it is essential to gain an understanding of the mechanistic actions of tamoxifen in these target tissues, particularly in the human uterine epithelial cell. Current opinion suggests that the tissuespecific action of tamoxifen is due to the regulation of ER-mediated gene transcription (reviewed Shang 2006). This hypothesis is supported by several gene expression studies performed using normal (Mutter et al. 2001, Pole et al. 2005) or cancerous primary endometrial cell cultures (Pole et al. 2004, Wu et al.
2005), and human breast or uterine cell lines (MCF-7; (Frasor et al. 2004) ECC-1; (Dardes et al. 2002)), which show evidence of a differential transcriptional response to different oestrogens. Nevertheless, the effect of tamoxifen treatment on gene expression patterns in ER-positive human uterine endometrial epithelial cells has not been fully elucidated.

Data from previous studies using primary uterine cultures, derived from clinical samples, have been difficult to interpret due to patient variability (Pole et al. 2004). In addition, the proliferative response of endometrial cells in culture to SERMs has been shown to be variable, largely due to conditional differences between dose, time of exposure or media components (Shah et al. 2004). In this study, we used an established human uterine-derived epithelial cell line (Ishikawa; (Anzai et al. 1989)), which is oestrogen-responsive (Holinka et al. 1986, Robertson et al. 2002) and shares many phenotypic features in common with normal human endometrial epithelial cells (Lessey et al. 1996) to investigate the variation and extent of gene expression changes following tamoxifen treatment. Global gene expression profiles were determined and compared following treatment with 4-hydroxytamoxifen (OHT, $\left.10^{-6} \mathrm{M}\right)$ or $17 \beta$-oestradiol $\left(\mathrm{E}_{2}, 10^{-8} \mathrm{M}\right)$. The altered expression of key oestrogen-responsive genes and proteins were investigated and the ability of $\mathrm{OHT}$ or $\mathrm{E}_{2}$ to influence Ishikawa cell proliferation was assessed.

\section{Materials and methods}

\section{Cell culture}

Ishikawa cells (ECACC, Wiltshire, UK) were routinely maintained in phenol-red-free RPMI 1640 (Invitrogen) medium containing $10 \%$ foetal calf serum (FCS, Hyclone, Northumberland, UK) and $2 \mathrm{mM}$ glutamine (Gmax, Sigma) and incubated at $37{ }^{\circ} \mathrm{C}$ with $5 \% \mathrm{CO}_{2}$ in vented flasks (BDBiosciences, Oxford, UK). For all dosing experiments, the medium was replaced with RPMI 1640 containing 10\% charcoal-stripped FCS (CSS, Hyclone) and $2 \mathrm{mM}$ glutamine (Gmax) for $72 \mathrm{~h}$ prior to treatment with $10^{-8} \mathrm{M} 17 \beta$-oestradiol $\left(\mathrm{E}_{2}\right.$; Sigma), reported to significantly increase proliferation in MCF7 cells (Vanparys et al. 2006), $10^{-6} \mathrm{M}$ (OHT; Sigma), which was shown to display both agonist and antagonist behaviour (Bramlett \& Burris 2003) and induce proliferation (Horner-Glister et al. 2005) in $\mathrm{ER}+$ Ishikawa cells, or ethanol $(0.1 \%)$ as the vehicle control. All experiments were performed in triplicate on Ishikawa cells between passage number 3 and 15 , and repeated three times. 


\section{Cell proliferation assay}

Ishikawa cells were seeded at $10^{4}$ cells per well in sixwell plates in RPMI 1640 medium supplemented with $10 \% \mathrm{CSS}$ and $2 \mathrm{mM}$ glutamine for $72 \mathrm{~h}$ prior to treatment with $17 \beta-\mathrm{E}_{2}\left(10^{-8} \mathrm{M}\right)$ or OHT $\left(10^{-6} \mathrm{M}\right)$, or ethanol $(0.1 \%)$ as the vehicle control in the same media. Media containing dose or ethanol was replenished daily and viable cell counts taken using the trypan blue exclusion method at 24,48 and $72 \mathrm{~h}$ using a Neubauer-improved haemocytometer.

\section{Confirmation of ER isoform expression}

Ishikawa cells were seeded to $75 \mathrm{~cm}^{2}$ vented flasks at $10^{6}$ cells per flask in either maintenance or dosing medium (described above) for $72 \mathrm{~h}$. After this time, cells were harvested following incubation with trypsin/EDTA (Invitrogen) for $\sim 5 \mathrm{~min}$ and counted using a haemocytometer. Viability was determined using trypan blue exclusion. The cells were collected by centrifugation at $1500 \mathrm{~g}$ for $5 \mathrm{~min}$ at $4{ }^{\circ} \mathrm{C}$ and the cell pellets were used for either RNA extraction or western blot analyses.

\section{Western blot analysis}

Whole cell lysates were prepared using protein extraction buffer according to the method of Song et al. (2002). Protein concentration was determined using the Bicinchoninic acid kit for protein determination (Sigma). A standard curve was created by dilutions of BSA (200-1000 $\mu \mathrm{g} / \mathrm{ml})$, which were used as a reference. SDS-PAGE and blotting performed as previously described (Horner-Glister et al. 2005). Human recombinant proteins for either ER $\alpha$ or ER $\beta$ (10 ng; Calbiochem, Nottingham, UK) were used as positive controls and run alongside a standard molecular weight ladder (BioRad). For ER $\alpha$ determination, blots were blocked with 5\% non-fat milk powder-PBS and probed using $\mathrm{H}-184$ rabbit polyclonal antibody (sc-7207 diluted 1:1000 in 3\% non-fat milk powderPBS, incubated overnight at $4{ }^{\circ} \mathrm{C}$ ) followed by HRPconjugated anti-rabbit secondary antibody (sc-2030, $1: 2500,1 \mathrm{~h}$ at room temperature; Santa Cruz Biotechnologies Inc., Heidelberg, Germany). ER $\beta$ blots were blocked with 5\% BSA-TBS and probed using GR39 mouse monoclonal antibody (Oncogene Research Products, Nottingham, UK; diluted 1:500 in 3\% BSATBS, incubated overnight at $4{ }^{\circ} \mathrm{C}$ ) followed by antimouse secondary antibody (sc-2031, 1:2500, $1 \mathrm{~h}$ at room temperature; Santa Cruz Biotechnologies Inc.; 1:2500, $1 \mathrm{~h}$ at room temperature). West Pico Super Signal chemiluminescence detection reagent (Pierce,
Perbio Science UK, Northumberland) was applied for $1 \mathrm{~min}$ and images captured using the GeneGnome chemiluminescence detection system (Syngene, Cambridge, UK). Blots were washed well with PBS and incubated overnight at $4{ }^{\circ} \mathrm{C}$ in PBS before being re-probed for actin (I-19, sc-1616, Santa Cruz Biotechnology Inc.; diluted 1:1000 in 3\% non-fat milk powder-PBS, incubated for $1 \mathrm{~h}$ at room temperature) followed by $1 \mathrm{~h}$ at room temperature with donkey antigoat secondary antibody (sc-2033, 1:5000, $1 \mathrm{~h}$ at room temperature) and densitometry was performed using the GeneTools software (Syngene).

\section{Alkaline phosphatase (AP) assay}

Cells grown for $48 \mathrm{~h}$ in RPMI 1640 medium containing $10 \%$ CSS and $2 \mathrm{mM}$ glutamine described above were trypsinised and seeded into 12 -well plates at $7.5 \times 10^{3}$ cells per well for a further $24 \mathrm{~h}$. The medium was then replaced with medium containing either: vehicle alone, $\mathrm{E}_{2}\left(10^{-8} \mathrm{M}\right)$, OHT $\left(10^{-6} \mathrm{M}\right)$, Faslodex $\left(10^{-6} \mathrm{M}\right)$, $\mathrm{E}_{2}+\mathrm{OHT}$, or $\mathrm{E}_{2}+$ Faslodex and the plates incubated at $37^{\circ} \mathrm{C}$ and the medium replenished every $48 \mathrm{~h}$. After 1, 3 and 5 days, the cells were washed with PBS and then lysed by freezing at $-80{ }^{\circ} \mathrm{C}$ for $30 \mathrm{~min}$. The alkaline phosphatase activity was determined using a 1-Step PNPP Kit (Pierce) following the manufacturers instructions. Briefly, after thawing the frozen cells, 1-Step PNPP solution $(500 \mu \mathrm{l})$ was added to each well and mixed with the cell extracts. The plates were then incubated at RT for $1 \mathrm{~h}$ on an orbital shaker. Stop solution $(2 \mathrm{~N} \mathrm{NaOH}, 100 \mu \mathrm{l})$ was added to each well, mixed and the lysates transferred to microfuge tubes. These were centrifuged at $12000 \mathrm{~g}$ for $2 \mathrm{~min}$ at RT and the supernatant $(200 \mu \mathrm{l})$ transferred to a 96 -well plate for colorimetric assessment. The absorbance was measured at $405 \mathrm{~nm}$ using a FluorOptima plate reader (BMG LabTech Ltd, Aylesbury, UK).

\section{Time course for gene expression using qRT-PCR analysis}

Ishikawa cells were seeded to six-well plates at $5 \times 10^{4}$ cells per well in dosing medium for $72 \mathrm{~h}$, prior to dosing. Cells were dosed with vehicle only, OHT or $\mathrm{E}_{2}$ at time 0 and harvested at 6, 12, 18 and $24 \mathrm{~h}$, and used for RNA extraction and RT-PCR. In addition, cultures were seeded at $1 \times 10^{4}$ cells per well, dosed in the same manner as above with dose replenished every $48 \mathrm{~h}$ and harvested at day 1,3 and 5 after dose for analysis of alkaline phosphatase, placental-like 2 (ALPPL2) expression in accordance with the alkaline phosphatase assay. 


\section{RNA extraction}

Total RNA was extracted using the RNeasy Kit (Qiagen) as described by the manufacturer, including the on-column RNAse-free DNAse I treatment. RNA was eluted in $50 \mu \mathrm{l}$ nuclease-free water, and diluted in the ratio of 1:100 before the concentration and purity of the RNA was determined spectrophotometrically by the $A_{260} / 280$ ratio and by using the Agilent Bio-Analyser (Agilent Technologies UK Ltd, West Lothian, UK). Only RNA with an $A_{260} / 280$ ratio of 1.9-2.1 and with no evidence of peak degradation (18S/28S) was used in this study.

\section{Synthesis of first strand cDNA}

Total RNA was reverse transcribed according to the manufacturer's instructions and all reagents were obtained from Roche Diagnostics: one microgram was primed using random hexamer primers $\left(0.08 A_{260}\right.$ units) at $65^{\circ} \mathrm{C}$ for $10 \mathrm{~min}$ then placed on ice. To a final volume of $20 \mu \mathrm{l}$, the following was added per reaction: reaction buffer $(1 \times)$, dNTP $(10 \mathrm{mM})$, Transcriptor Reverse Transcriptase (10 Units) and Protector RNase inhibitor (20 Units), and incubated at $25^{\circ} \mathrm{C}$ for $10 \mathrm{~min}$ followed by $55^{\circ} \mathrm{C}$ for $30 \mathrm{~min}$.

\section{qRT-PCR}

Real-time PCR was performed using the LightCycler 2.0 system and software (Roche Molecular Biochemicals). Preliminary results showed the GAPDH housekeeping gene to be up-regulated in response to $\mathrm{E}_{2}$ at $24 \mathrm{~h}$ (data not shown). Therefore, we used the Housekeeping Gene Selection Kit (Roche) to select an alternative and found that 5-aminolevulinic acid synthase (ALAS) expression was not affected by any of the treatments, and was used throughout the study. One microlitre of cDNA was amplified using sequence-specific, intron-spanning primers designed using the Roche Universal ProbeLibrary Assay Design Centre software unless otherwise stated. PCR was performed in a capillary format using DNA Master FastStart SYBR green I (Roche) according to the manufacturer's instructions, to a final volume of $20 \mu \mathrm{l}$ containing cDNA $(1 \mu \mathrm{l})$, specific primers $(10 \mathrm{pmol}$ each forward and reverse primer) and FastStart DNA Master SYBR green I mix $(1 \times)$ containing FastStart DNA Taq Polymerase for Hotstart PCR. Samples were taken through a pre-incubation step, amplification cycles (including denaturation, annealing and extension segments $>45$ cycles) and melting curve analysis. Fluorescence was acquired as a single reading at the end of the extension segment of each cycle, and continuously during the melting curve analysis. The size of amplicons generated was confirmed by agarose gel electrophoresis (2\% agarose in $1 \times \mathrm{TAE}$ buffer containing ethidium bromide) alongside a $100 \mathrm{bp}$ DNA ladder (Promega). Each PCR run included $3 \times$ calibrator cDNA control samples prepared from untreated Ishikawa RNA and a no-template, negative control. Serial dilutions of the calibrator cDNA were used to create co-efficiency files for each primer set versus ALAS (housekeeping gene) and to normalise across PCR runs. Gene expression was quantified using the RelQuant software (Roche). Primer sequences were: ESR1 (F: GGCTACATCATCTCGGTTCC, R: TCAGGGTGCTGGACAGAAA), ALPPL2 (F: TGTTACCGAGAGCGAGAGC, R: GTGGGTCTCTCCGTCCAG), CKB (F: CTTCAGAAGCGAGGCACAG, R: ACTCCGTCCACCACCATCT), CASPASE 3 (F: TGTGAGGCGGTTGTAGAAGA, R: GGGCTCGCTAACTCCTCAC), CABLES1 (F: TCGCGACAGTACCCAAGTC, R: TCAAACTCACTGCA-CCAGTTG), NEDD8 (F: TCTACAGTGGCAAGCAATGA, R: GCCTAAGACCACCTCCTCCT), VINEXINB (F: TCAGATACACTGGACCCCGTA, R: CATGACATCCACCCTGTCC), GREB1* (F: CCAAGAATAACCTGTTGGCCCTGC, R: GACATGCCT GCGCTCTCATACTTA)*(Rae et al. 2005). All oligos were synthesised by Sigma-Genosys.

\section{Microarray analysis}

Ishikawa cells were seeded in triplicate $175 \mathrm{~cm}^{2}$ flasks at either $2.5 \times 10^{6}(24 \mathrm{~h})$ or $2 \times 10^{6}(48 \mathrm{~h})$ cells per flask in dosing medium for $72 \mathrm{~h}$. Cells were dosed with $10^{-8} \mathrm{M}$ $\mathrm{E}_{2}, 10^{-6} \mathrm{M}$ OHT or ethanol, and then harvested at 24 and $48 \mathrm{~h}$ by trypsinisation. The cell number was determined using a haemocytometer, cells pelleted by centrifugation at $1500 \mathrm{~g}$ for $5 \mathrm{~min}$ at $4{ }^{\circ} \mathrm{C}$ and RNA extracted.

Microarray analyses using $\mathrm{Cy} 3, \mathrm{Cy} 5$ forward and reverse dye bias labelling were performed on spotted oligo arrays obtained from the Medical Research Council Human Genome Mapping Project Resource Centre (MRC HGMP-RC, Cambridge, UK). These arrays represent $\sim 19000$ human genes, each gene being present in duplicate and the full set printed on two separate slides. Triplicate experiments were performed at 24 and $48 \mathrm{~h}$ for both $\mathrm{E}_{2}$ and $\mathrm{OHT}$. In total, 12 slides were used per treatment, per time point. Labelled cDNA was prepared from total RNA extracted from treated $\left(E_{2}\right.$ or OHT) or control Ishikawa cells by the annealing of $8 \mu \mathrm{g} / \mu \mathrm{l}$ oligo $\mathrm{dT}_{25}$ at $70^{\circ} \mathrm{C}$ for $8 \mathrm{~min}$, with a graduated reduction of temperature to $42{ }^{\circ} \mathrm{C}$ over $30 \mathrm{~min}$. Subsequently, to the reaction mixture was added: RNAsin (20 Units, Promega), dithiothreitol $(0.1 \mathrm{M})$, reaction buffer $(5 \times)$, Superscript II reverse transcriptase 
(2 Units, Roche), dNTP mix containing a final concentration of $0.5 \mathrm{mM}$ each, except $0.2 \mathrm{mM}$ dTTP (Pharmacia), $0.1 \mathrm{mM} \mathrm{Cy3} \mathrm{(control)} \mathrm{or} \mathrm{Cy5} \mathrm{(test)} \mathrm{fluor-dUTP}$ (Amersham) and DEPC-treated Ultra Pure $\mathrm{H}_{2} \mathrm{O}$ to a final volume of $41 \mu \mathrm{l}$ followed by incubation at $42{ }^{\circ} \mathrm{C}$ for $1 \mathrm{~h}$. Dye Bias (reverse) labelling was performed on the same batch of RNA by swapping sample labelling where Cy3 becomes test in a separate reaction. RNA was hydrolysed by the addition of EDTA $(0.5 \mathrm{M})$, SDS $(10 \% \mathrm{w} / \mathrm{v})$ and $\mathrm{NaOH}(3 \mathrm{M})$ and $10 \mathrm{~min}$ incubation at $70^{\circ} \mathrm{C}$. After cooling, the mixture was neutralised by the addition of $\mathrm{HCl}(2 \mathrm{M})$, Tris- $\mathrm{HCl}(1 \mathrm{M}, \mathrm{pH} 7.5)$ and tRNA $(4 \mu \mathrm{g} / \mathrm{ml}$, Invitrogen) to a final volume of $60 \mu$ l. Labelled probes were purified using re-hydrated Centri-Sep columns (Cambio Ltd, Cambridge, UK). Next, PolyA $(1 \mu \mathrm{g})$ was added to one of the probes and human Cot $1 \mathrm{DNA}(10 \mu \mathrm{g}$, Invitrogen) to the other to avoid non-specific binding of Alu fragments to the target sequence. Samples were dried down using a SpeedVac before being prepared for hybridisation. The following mix was added to one dried probe per control/treated pair: $21 \mu$ hybridisation buffer prepared by adding formamide ( $1 \mathrm{ml}$, Sigma), $50 \times$ Denhardt's solution (100 $\mu \mathrm{l}$, Sigma), ultra pure $\mathrm{H}_{2} \mathrm{O}$ $(200 \mu \mathrm{l}), 10 \%$ SDS (100 $\mu \mathrm{l}$, freshly made) and filtered through a $0.45 \mu \mathrm{m}$ disc (Millipore UK Ltd, Watford, UK) using a syringe and a $20 \times$ saline phosphate EDTA solution $(9 \mu \mathrm{l})$ containing $\mathrm{NaCl}(3 \mathrm{M}), \mathrm{NaH}_{2} \mathrm{PO}_{4}(1 \mathrm{mM})$ EDTA and adjusted to $\mathrm{pH} 7.4$ and mixed by gentle vortexing. This was then added to the other dried probe, mixed and heat-denatured at $100{ }^{\circ} \mathrm{C}$ for $2 \mathrm{~min}$ and allowed to cool to $42{ }^{\circ} \mathrm{C}$. The combined test + control samples were then hybridised to paired spotted oligonucleotide microarray slides by incubation inside humidified microarray chambers, which were sealed and immersed in a water bath at $42{ }^{\circ} \mathrm{C}$ overnight. A series of stringent washes were performed as follows: preheated $1 \times \mathrm{SSC}(0.15 \mathrm{M} \mathrm{NaCl}$ and $0.015 \mathrm{M}$ sodium citrate) solution containing $0.03 \% \operatorname{SDS}(2 \times 10 \mathrm{~min})$ at $50{ }^{\circ} \mathrm{C}$, followed by $0.2 \times \mathrm{SSC}$, then $0.05 \times \mathrm{SSC}$ (both $2 \times 5 \mathrm{~min})$ at RT. Slides were quickly transferred to a centrifuge and centrifuged at $200 \mathrm{~g}$ for $10 \mathrm{~min}$ to dry and avoid background staining.

\section{Scanning and analysis of cDNA microarrays}

Information on the location and identity of the genes represented on the slides was contained in .gal files obtained from HGMP. These were loaded onto the scanner prior to use. The pixel intensity for hybridization was determined using an Axon 4000A scanner and GenePix software (Axon Instruments, Union City, CA, USA) version 3.0.6.

\section{Statistical analysis}

\section{Microarray data}

The data were normalised, condensed and analysed statistically to a final measure of differential gene expression with a false positive detection rate of $5 \%$ as previously described (Zhang \& Gant 2004) based on the program accessible at http://www.le.ac.uk/mrctox/ microarray-lab. Changes in gene expression were expressed as the normalised $\log _{2}$ ratio of median fluorescence. Genes having a value $P<0.05$ in a twotailed $t$ test were regarded as being significantly changed in expression, when compared with the control. Other statistical analysis was performed using Minitab release 14.13 (Minitab Inc., PA, USA). Differences between groups were tested using ANOVA with Fisher's test for significance at the 5\% level.

\section{Analysis of gene function}

The Gene-Ontology database (GO: http://www.geneontology.org) was used to annotate the gene expression profiles to allow further analysis. GOstat (http://gostat.wehi.edu.au/) computes GO statistics of a list of genes selected from a microarray and displays statistically over-represented GO terms within a group of genes. Probability of significance of pathway was determined by DAVID 2.1 beta, functional annotation program (http://david.abcc.ncifcrf.gov/).

\section{Results}

\section{$E R \alpha$ and $\beta$ protein expression in Ishikawa cells}

Western blot analysis of whole cell lysates with human $\mathrm{ER} \alpha$ and $\mathrm{ER} \beta$ recombinant proteins as positive controls, detected independently with isoform-specific antibodies, showed the presence of both ER $\alpha$ and ER $\beta$ at their expected molecular masses of 66 and $53 \mathrm{kDa}$ respectively (Fig. 1A and B). Both proteins were expressed when cells were maintained in culture media containing either normal FCS (lane 3) or CSS (lane 4). Additional lower molecular mass ER $\beta$ isoforms (1B) were also detected as has been shown previously for Ishikawa cells (Taylor et al. 2002).

\section{Effect of OHT and $E_{2}$ on Ishikawa cell proliferation}

Ishikawa cells treated with ethanol only (controls) proliferated at a steady rate and at $3.8 \times 10^{5}$ cells/well at the 72-h time point, had not yet reached plateau phase. By contrast, Ishikawa cells treated with either $\mathrm{OHT}$ or $\mathrm{E}_{2}$ initially mirrored the growth pattern of controls (Fig. 2); however, the rate of proliferation was significantly increased by the addition of either $\mathrm{OHT}$ or $\mathrm{E}_{2}$ during 
A

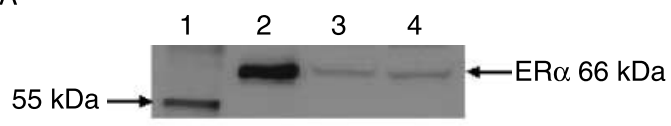

B

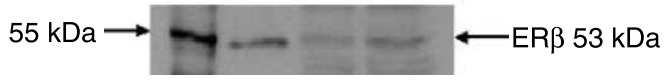

Figure 1 The presence of $E R \alpha(A)$ and $E R \beta(B)$ was confirmed by Western blot analysis on Ishikawa, whole cell lysates resolved on $10 \%$ SDS-PAGE. The molecular mass ladder in Lane 1 indicates the position of the $55 \mathrm{kDa}$ band. Recombinant proteins for either $E R \alpha$ or $E R \beta$ protein were included as positive controls (Lane 2) and indicate products of the expected size for each protein. Ishikawa cells were grown in media containing $10 \%$ FCS (Lane 3 ) or 10\% charcoal-stripped-FCS (Lane 4) for $72 \mathrm{~h}$ (media replenished at $48 \mathrm{~h}$ ), prior to harvesting and western blot analysis.

the second and third days of culture $(P<0.001)$. By $72 \mathrm{~h}$ of stimulation, the cell numbers for cultures treated with OHT or $\mathrm{E}_{2}$ were almost double that of the controls at $6.53 \times 10^{5}$ and $6.93 \times 10^{5}$ cells/well respectively.

\section{Expression of oestrogen-responsive genes}

In order to choose a relevant time point for global gene expression analysis, quantitative real-time RT-PCR was used to monitor the expression of $\mathrm{ER} \alpha$ and selected oestrogen-responsive genes at 6,12,18 and $24 \mathrm{~h}$. The levels of ER $\alpha$ increased in cultured Ishikawa cells by approximately threefold during the $24 \mathrm{~h}$ period, but neither $\mathrm{E}_{2}$ nor $\mathrm{OHT}$ affected the basal

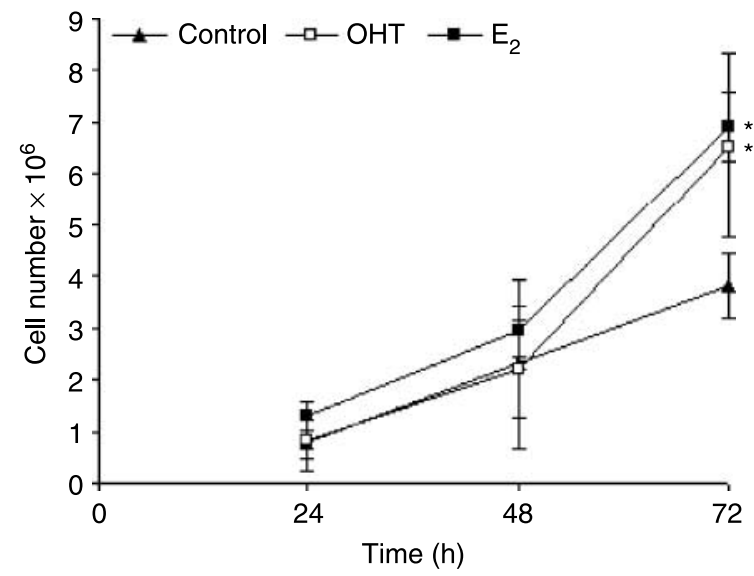

Figure 2 Effects of $\mathrm{OHT}$ and $\mathrm{E}_{2}$ on cell proliferation. Cells were seeded in six-well plates and serum starved in RPMI 1640 containing charcoal-stripped FCS for $72 \mathrm{~h}$ prior to dosing. Control cells were treated with vehicle (ethanol) only. Viable cell counts were performed daily on triplicate wells using trypan blue exclusion. $\boldsymbol{\Delta}$, controls; $\square, \mathrm{OHT} ; \mathbf{\square}, \mathrm{E}_{2}$. Results represent the mean \pm s.D. of three experiments. ( ${ }^{\dagger}$ Significantly different from time 0 ; *significantly different from controls at the corresponding time point by ANOVA $P<0.001)$.
$\mathrm{ER} \propto$ transcript levels (Fig. 3A). By contrast, both $\mathrm{E}_{2}$ and OHT significantly increased the presence of CKB transcripts at $24 \mathrm{~h}$ (by 2.7- and 2.1-fold respectively when compared with the control; $P<0.001$; Fig. 3B), whilst $\mathrm{E}_{2}$ increased GREB1 transcript levels at 12, 18 and $24 \mathrm{~h}$ (by 1.8-, 1.9- and 2.5-fold respectively; $P<$ 0.001; Fig. 3C). The effect of OHT on GREB1 transcript levels was not significant.

\section{AP activity and expression of ALPPL2}

AP activity was used as a protein marker assay for oestrogen agonist and antagonist activity. Figure 4A shows an induction of AP activity in response to both OHT (2.5-fold) and $E_{2}$ (13.4-fold) at 5 days after treatment. Faslodex (ICI $181780 ; 10^{-6} \mathrm{M}$ ), a pure antioestrogen, was included as a negative control and no induction of AP activity was observed (Fig. 4A and C). Cultures were dosed with $\mathrm{E}_{2}+\mathrm{OHT}$ or $\mathrm{E}_{2}+$ Faslodex for 5 days to assess the oestrogen antagonistic potential of OHT in this cell line (Fig. 4C). $\mathrm{E}_{2}$ treatment resulted in a dramatic increase in AP activity (1.9-fold on day 3 to 13.4-fold on day 5), which was significantly $(P<$ 0.001 ) higher than control, whilst OHT exhibited a partial oestrogen agonist effect at 5 days (1.1- to 2.5fold). Both OHT and Faslodex were able to significantly $(P<0.001)$ antagonise the oestrogenic action of $E_{2}$ in these cells, resulting in the abrogation of increased AP activity induced by $E_{2}$. Most notably, the AP activity measured when co-dosed with $\mathrm{E}_{2}+\mathrm{OHT}$ was significantly different from controls, demonstrating the partial oestrogen agonist action of OHT in this cell type, which remains in the presence of $E_{2}$.

We were interested to see if this increased activity would coincide with the altered expression of any specific alkaline phosphatase gene which might be present on the array. The only one to be significantly up-regulated on the array was ALPPL2 in response to $\mathrm{E}_{2}$ at $48 \mathrm{~h}$ (by 3.7-fold). Using real-time PCR (Fig. 4B), we observed a significant $(P<0.001)$ up-regulation of ALPPL2 in response to $E_{2}$ at 1, 3 and 5 days following treatment. In addition, OHT also induced a significant increase in expression at day 5 .

\section{Microarray analysis}

Figure 5 summarises the total number of significant changes $(P<0.05)$ in gene expression in Ishikawa cells treated for 24 or $48 \mathrm{~h}$ with either $\mathrm{E}_{2}$ or OHT. Results indicate that the cellular response to $\mathrm{E}_{2}$ and $\mathrm{OHT}$ is quite different. At $24 \mathrm{~h}, \mathrm{E}_{2}$ significantly $(P<0.05)$ changed the expression of 534 genes, while OHT changed 716 in a manner unique to each ligand, whilst the altered expression of only 46 genes was common to both. 
A

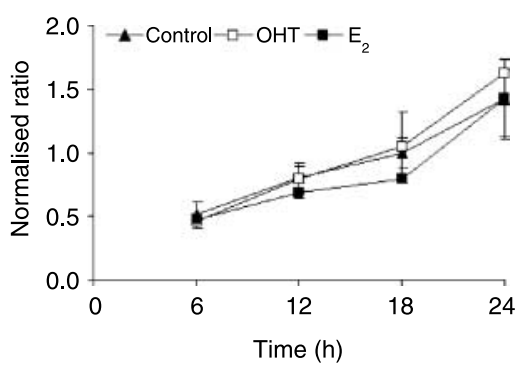

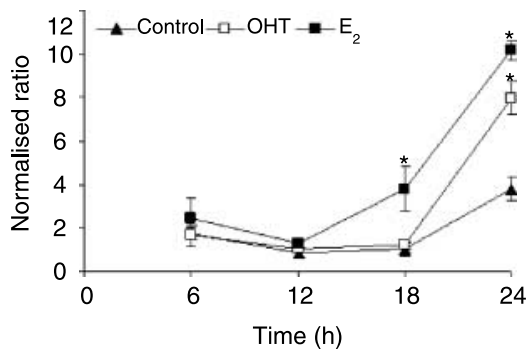

C

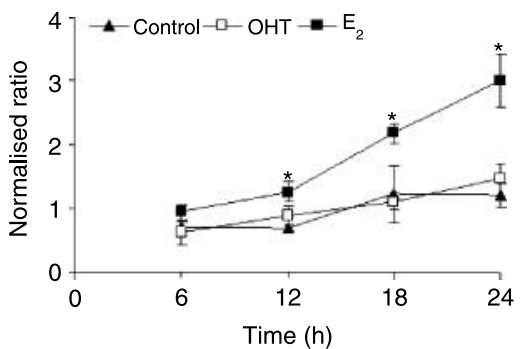

Figure 3 LightCycler RT-PCR on cDNA from Ishikawa cells dosed with $\mathrm{E}_{2}$ or OHT for $6,12,18$ and $24 \mathrm{~h}$ for $(\mathrm{A}) \mathrm{ER} \alpha$, and the oestrogenresponsive genes (B) CKB and (C) GREB1. $\boldsymbol{\Delta}$, controls; $\square, \mathrm{OHT} ; \boldsymbol{\square}, \mathrm{E}_{2}\left({ }^{*} P<0.001\right.$ ANOVA when compared with control). Expression was normalised to ALAS and relative quantification was performed using the LightCycler RelQuant software.

Similarly, at $48 \mathrm{~h}, \mathrm{E}_{2}$ induced 240 and OHT 335 unique gene changes, whilst only 13 were significantly changed by both treatments. Overall, the number of genes up- or down-regulated by OHT at $24 \mathrm{~h}$ was approximately equal $(\uparrow 49 \%, \downarrow 51 \%)$, whilst at $48 \mathrm{~h}$ with OHT and with $\mathrm{E}_{2}$ at both time points, there were more up-regulated genes than down $(\sim \uparrow 60 \%, \downarrow 40 \%)$. Data have been deposited in accordance with Microarray Gene Expression Data Society's MIAME recommendations in the GEO database (http://www.ncbi.nlm.nih.gov/geo). The accession numbers are as follows: GSE3762, Platforms GPL2914 \& GPL3218 and Samples GSM86306-86353. Individual gene changes are also available as supplemental data for Fig. 5 .

\section{qRT-PCR validation of microarray data}

In order to validate the microarray data, the expression of selected genes altered by $\mathrm{E}_{2}$ or OHT in the array data were confirmed using qRT-PCR, and normalised to ALAS expression. The fold change in gene expression (compared to control) was taken from the PCR and array experiments and tabulated (Table 1). Comparison of the two experimental data sets showed excellent correlation with a regression coefficient of 0.91 . In each case, the direction of altered expression was consistent (i.e. genes up-regulated in the array data were shown to be over-expressed when compared with control by qRT-PCR).

\section{Microarray data analysis: oestrogen-responsive genes}

Array data were compared with known oestrogenresponsive genes on the Dragon Oestrogen Responsive Gene Database v 2.0 (ERGDB; Tang et al. 2004). Out of the 1069 oestrogen-responsive genes present in the above database, 900 were also represented on the array used in this study.

We investigated the significance of an identifiable ERE motif in the promoter region of this group of genes, as an indication of potential for classical ER-mediated transcriptional activation by either $\mathrm{OHT}$ or $\mathrm{E}_{2}$ (individual gene changes provided as supplemental data). The data indicate that at $24 \mathrm{~h}$, the expression of two genes with a known ERE was changed after $\mathrm{E}_{2}$ or OHT treatment. These were, gene-regulated by oestrogen in breast cancer; GREB1 (up-regulated $\mathrm{E}_{2} ; 2.35$-fold, OHT; 1.29 -fold) and proteasome subunit $\beta$-type 6; PSMB6 (proteosome subunit beta, type 6) (down-regulated $\mathrm{E}_{2}$; 0.68 -fold, OHT 0.48 -fold). After $48 \mathrm{~h}$, only glyceraldehyde-6-phosphate dehydrogenase was up- regulated following both $\mathrm{E}_{2}$ and $\mathrm{OHT}$ treatment (1.26 and 2.46 respectively). Out of the oestrogen-responsive genes induced by $\mathrm{E}_{2}$ at $24 \mathrm{~h}, 68 \%$ contained an ERE and this increased to $81 \%$ at $48 \mathrm{~h}$. Only three genes without an ERE were altered at $48 \mathrm{~h}$; one of these (PLK1; polo-like kinase 1) was significantly up-regulated at both time points with $\mathrm{E}_{2}$ (24 h, 1.32-fold; $48 \mathrm{~h}, 1.41$-fold), 

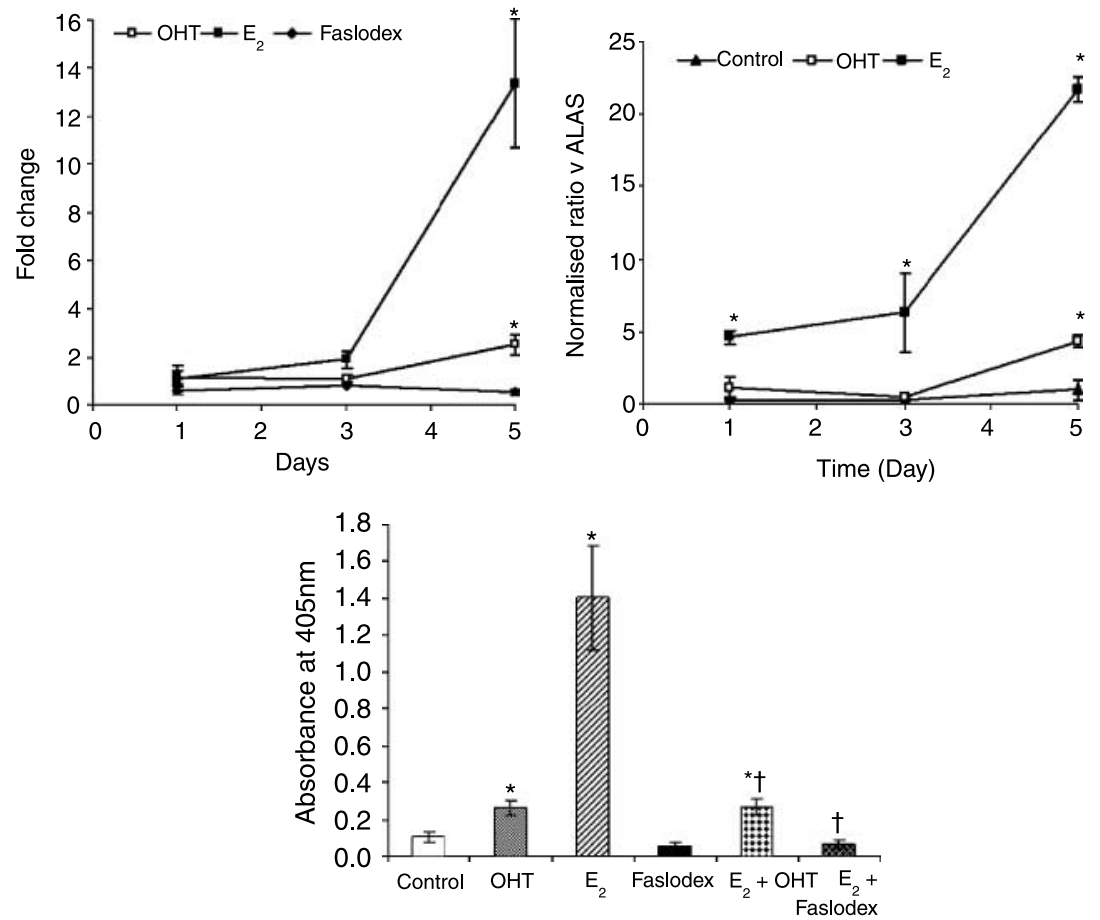

Figure 4 Alkaline phosphatase activity and expression of ALPPL2. Ishikawa cells were serum-starved for $72 \mathrm{~h}$ before dosing with either OHT $\left(10^{-6} \mathrm{M}\right), \mathrm{E}_{2}\left(10^{-8} \mathrm{M}\right)$ or ethanol (control) on days 0,2 and 4. (A) Alkaline phosphatase activity was assessed at days 1, 3 and 5. $\square, \mathrm{OHT} ; \boldsymbol{\square}, \mathrm{E}_{2} ; \diamond$, Faslodex. (B) Expression of ALPPL2 was determined at days 1, 3 and 5. $\mathbf{\Delta}$, controls; $\square, \mathrm{OHT} ; \boldsymbol{\square}, \mathrm{E}_{2} .{ }^{\star}{ }^{\star} P<$ 0.001 ANOVA when compared with controls). (C) Ishikawa cells were serum-starved for $72 \mathrm{~h}$ before dosing with either OHT (10 $\left.{ }^{-6} \mathrm{M}\right)$, $\mathrm{E}_{2}\left(10^{-8} \mathrm{M}\right), 10^{-6} \mathrm{M}$ Faslodex or the combinations $\mathrm{OHT}+\mathrm{E}_{2}$, and Faslodex $+\mathrm{E}_{2}$ on days 0,2 and 4 . Control cultures were treated with ethanol only. Alkaline phosphatase activity was assessed at day 5. ( ${ }^{\star}$ Significantly different from control at the corresponding time point; ${ }^{\dagger}$ significantly different from $\mathrm{E}_{2}$ alone: ANOVA $\left.P<0.001\right)$.

whilst the transcription factor subunit RUNX1 was down-regulated at $48 \mathrm{~h}$ with both treatments $\left(\mathrm{E}_{2} ; 0.91\right.$ fold, OHT; 0.76-fold). The number of OHT-induced oestrogen-responsive genes with an ERE was $64 \%$ at $24 \mathrm{~h}$, which was only marginally higher at $48 \mathrm{~h}(70 \%)$. It is of interest to note that the ERGDB is not an exhaustive list of oestrogen-responsive genes, for example TRIM16 (also known as oestrogen-responsive B-box protein EBBP (oestrogen responsive B box protein)), which was up-regulated with both $\mathrm{E}_{2}$ and $\mathrm{OHT}$ in our array data at $24 \mathrm{~h}$ (1.43 and 1.32 respectively), and has been reported to be oestrogen-responsive, and tamoxifenregulated in human mammary epithelial cells (Liu et al. 1998) is not included in this database.

\section{Microarray data analysis: functional annotation}

The allocation of significantly changed genes according to the Gene Ontology project (http://www. geneontology.org/), allowed the data to be ranked according to the importance of functional information associated with the individual genes. This approach, is complemented by GoStat analysis, a method which was developed to find statistically over-represented
GO terms within a group of genes. Many of the more general $G O$ terms including cellular biosynthesis and lipid metabolism featured in both analyses and those terms associated with cell cycle, mitosis and cell proliferation were most prominent. Terms unique to OHT were not so informative with ribonucleotide metabolism and biosynthesis predominating, although protein folding and localisation and cell motility also featured. Since both OHT and $\mathrm{E}_{2}$ increased cell proliferation relative to controls, further analysis of the archetypal GO terms 'cell cycle' and 'cell death' are presented (Table 2). Dosing of Ishikawa cells with OHT for $24 \mathrm{~h}$ resulted in more down-regulated genes (71\%), including cyclins B1, $\mathrm{E}_{2}, \mathrm{G} 2$ and cell division cycle CDC7 and CDC16, than up-regulated genes. By contrast, following $\mathrm{E}_{2}$ treatment, a higher number was up-regulated than down (55\%) including cyclin D2, BRCA2 and MAPK13, whilst it shared the downregulation of cyclins B1 and G2 with OHT treatment. In agreement with the cell proliferation assay, none of the cell death associated genes were altered with OHT at $24 \mathrm{~h}$ (individual gene changes provided as supplemental data). 


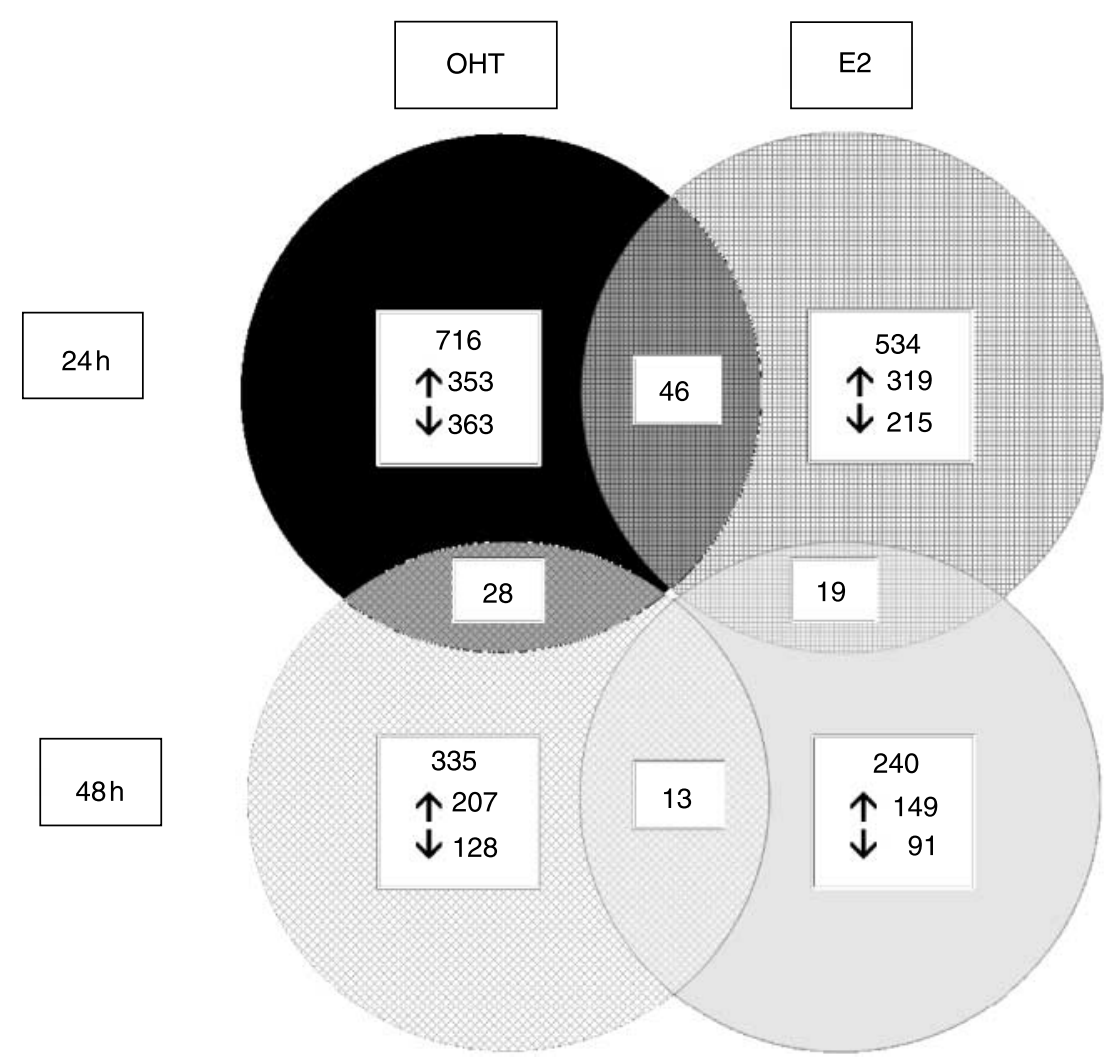

Figure 5 Venn diagram showing the number of significant gene changes $(P<0.05)$ in response to 24 or $48 \mathrm{~h}$ treatment with either $\mathrm{E}_{2}$ $\left(10^{-8} \mathrm{M}\right)$ or OHT $\left(10^{-6} \mathrm{M}\right)$ in Ishikawa cells. The numbers given within each of the circles represents the total number of significantly changed genes, which are unique to that time and treatment, and the manner in which they are regulated (up or down when compared with the control). Overlaps indicate the number of commonly changed genes between time/ligand. No genes were significantly changed at both time points, and by both ligands.

\section{Discussion}

The aim of this study was to define the transcriptional response of a model system that represents the human uterine epithelial cell to treatment with $\mathrm{E}_{2}$ or the
SERM, tamoxifen, in order to evaluate the differential effects of oestrogenic compounds on this cell type. In breast cancer patients, tamoxifen is thought to have an oestrogen agonist action on the uterus (White 2001)

Table 1 Validation of microarray data by quantitative real-time PCR

\begin{tabular}{lccc}
\hline Gene & Accession no. & Microarray fold change \pm s.o. & RT-PCR fold change \pm s.o. \\
\hline A. OHT & & & $1.25 \pm 0.20 \mathrm{NS}$ \\
GREB1 & NM_014668 & $1.29 \pm 0.16$ & $2.14 \pm 0.20$ \\
CKB & NM_001823 & $1.72 \pm 0.90 \mathrm{NS}$ & $0.75 \pm 0.01$ \\
CCNG2 & NM_004354 & $0.73 \pm 0.07$ & $0.68 \pm 0.28 \mathrm{NS}$ \\
NEDD8 & NM_006156 & $0.57 \pm 0.09$ & $0.68 \pm 0.20 \mathrm{NS}$ \\
VINEXIN $\beta$ & NM_005775 & $0.39 \pm 0.08$ & \\
B. E2 & & & $2.09 \pm 0.13$ \\
CABLES1 & AK025627 & $2.39 \pm 0.24$ & $2.52 \pm 0.34$ \\
GREB1 & NM_014668 & $2.35 \pm 0.27$ & $2.70 \pm 0.11$ \\
CKB & NM_001823 & $1.84 \pm 0.39$ & $0.62 \pm 0.01$ \\
CCNG2 & NM_004354 & $0.67 \pm 0.06$ & $0.80 \pm 0.14$ NS \\
CASP3 & NM_004346 & $0.67 \pm 0.02$ & \\
\hline
\end{tabular}

S.D., standard deviation; NS, not significant. A selection of genes, whose expression was significantly changed by microarray analysis was confirmed using SYBR green I real-time PCR on the LightCycler system all changes were significant relative to controls $P<0.05$ except those labelled NS. Data are presented as fold-change relative to control where values $<1$ are down-regulated, and those $>1$ are up-regulated. 
Table 2 Gene ontology analysis of effects of treatment with either 4-hydroxytamoxifen $(\mathrm{OHT})$ or oestradiol $\left(\mathrm{E}_{2}\right)$ on changes in gene expression associated with terms cell cycle or cell death

\begin{tabular}{|c|c|c|c|c|c|c|}
\hline \multirow[b]{2}{*}{ Time } & \multirow[b]{2}{*}{ GO term } & \multirow[b]{2}{*}{$P$ value ${ }^{\star}$} & \multicolumn{2}{|c|}{ OHT } & \multicolumn{2}{|c|}{$E_{2}$} \\
\hline & & & Up & Down & Up & Down \\
\hline \multirow[t]{2}{*}{$24 \mathrm{~h}$} & Cell cycle & $1.37 \times 10^{-4}$ & 14 & 34 & 22 & 18 \\
\hline & Cell death & - & 0 & 0 & 12 & 10 \\
\hline \multirow[t]{2}{*}{$48 \mathrm{~h}$} & Cell cycle & $5.25 \times 10^{-4}$ & 9 & 7 & 13 & 5 \\
\hline & Cell death & $2.05 \times 10^{-2}$ & 2 & 6 & 11 & 3 \\
\hline
\end{tabular}

*Probability of significance of pathway determined by DAVID 2.1 beta, functional annotation program (http://david.abcc.ncifcrf.gov). Individual gene identity available as supplementary data.

and the Phase 1 metabolite, OHT shows in the order of 100-fold greater oestrogen agonist activity in the uterus than tamoxifen (Furr \& Jordan 1984). Here, we present evidence of a differential response in terms of transcript levels following treatment of Ishikawa cells with either OHT or $\mathrm{E}_{2}$ at 24 and $48 \mathrm{~h}$.

The Ishikawa cells maintained their ER $\alpha$ and ER $\beta$ expression in culture and unlike MCF-7 cells, continued to grow well in medium supplemented with CSS, in the absence of $E_{2}$. The oestrogen-responsive nature of these cells was demonstrated by a significant increase in the rate of proliferation in response to both $\mathrm{E}_{2}$ and $\mathrm{OHT}$, in agreement with other studies (Croxtall et al. 1990, Shah et al. 2004, 2005, Vivacqua et al. 2006), a marked increase in alkaline phosphatase activity and increased expression of known oestrogen-responsive genes, such as $C K B$ and GREB1. There is good agreement that alkaline phosphatase activity in Ishikawa cells is positively regulated by oestrogens in an ER-dependent manner and is considered as a very sensitive means to assess ER agonist and antagonist activity (Holinka et al. 1986, Littlefield et al. 1990, Kasiotis et al. 2006). This was confirmed by our studies where both OHT and $\mathrm{E}_{2}$ independently increased AP activity, demonstrating the partial oestrogen agonist activity of OHT. It is of interest that this level of activity remains in the presence of $E_{2}$, where OHT is also acting as an efficient antagonist. By contrast, co-dosing with the pure anti-oestrogen Faslodex, which binds to and degrades the ER (Wakeling 2000) rather than compete for the occupancy of the receptor, abolished the $\mathrm{E}_{2}$-induced $\mathrm{AP}$ activity to below that of controls, suggesting that the effect of OHT on AP activity maybe through a subtly different mechanism than with $E_{2}$. There are four alkaline phosphatase isozymes: placental, placental-like, intestinal and tissue non-specific (liver/bone/kidney). We show here that the specific gene likely to be involved in the induction of alkaline phosphatase activity in Ishikawa cells is ALPPL2. The expression of ALPPL2 was up-regulated on the microarray in response to both $\mathrm{OHT}$ and $\mathrm{E}_{2}$, and this was confirmed by qRT-PCR analysis over 5 days resulting in a significant increase in expression, albeit to different extents, mirroring the effect observed in the AP assay.

\section{Diverse gene expression profiles are dictated or influenced by ligand binding}

The magnitude of gene expression changes, which were largely unique to ligand at either time point investigated and the minimal overlap between profiles, implies that OHT does not directly mimic $\mathrm{E}_{2}$, but rather orchestrates a cellular response of it own, despite acting via the same receptors. In addition, this study highlights the extent of influence that oestrogenic compounds have on the gene expression profile of uterine epithelial cells and gives weight to the hypothesis that the differential effects seen in the uterine endometrium might be mediated by specific OHT-regulated gene transcription pathways (Shang 2006).

\section{Gene ontology: analysis of gene expression.}

Analysis of gene expression changes by programs such as DAVID http://niaid.abcc.ncifcrf.gov/or GoMiner http://discover.nci.nih.gov/gominer/ showed a number of significant GO categories and enrichment common to both OHT and $E_{2}$. Out of these, the terms protein biosynthesis, cellular protein metabolism and cell cycle are consistent with the induction of cell proliferation. In response to $\mathrm{E}_{2}$, CASPASE 3 (CASP3), which is intimately involved in cell death decisions was one gene shown to be down-regulated at $24 \mathrm{~h}$. In some tissues, including neuronal cells and cardiac myocytes, $\mathrm{E}_{2}$ protects against cell death, in part, by down-regulating CASPASE 3 expression (Pelzer et al. 2000, Rau et al. 2003). Such protection may play a role in the actions of $\mathrm{E}_{2}$ on Ishikawa cells but there is no evidence for this following OHT treatment at this time point, suggesting that $\mathrm{E}_{2}$ and OHT augment uterine epithelial cell proliferation and survival through subtly different mechanisms. 


\section{Differential expression of key genes in a uterine cell line}

The transcriptional behaviour of GREB 1 (gene-regulated by oestrogen in breast cancer) was particularly prominent in this dataset as up-regulated by both $\mathrm{OHT}$ and $\mathrm{E}_{2}$ at $24 \mathrm{~h}$ on the array. GREB1 was identified as an early response gene-regulated by ER $\alpha$ in the three ER-positive breast cancer cell lines, MCF-7, T47D and BT-474, where it was one of only three genes to be significantly induced in all three cell lines (others included pS2 and SDF-1), and by contrast also repressed by OHT or Faslodex (Rae et al. 2005). In addition, the ERE present in the GREB1 promoter was shown to be directly targeted by the ER $\alpha$ following $\mathrm{E}_{2}$ stimulation (Lin et al. 2004). Although the cellular function of GREB1 has yet to be fully defined, there is increasing evidence, in particular its pattern of expression and regulation by $\mathrm{E}_{2}$, to imply that it might be critically involved in the regulation of hormonal cancers (Ghosh et al. 2000, Rae et al. 2005). The negative cell cycle regulator cyclin $\mathrm{G} 2$ (CCNG2), which was recently identified as a primary ER target gene in MCF-7 breast cancer cells where it was robustly down-regulated by oestrogen but not OHT (Stossi et al. 2006), was downregulated by both $\mathrm{OHT}$ and $\mathrm{E}_{2}$ in Ishikawa cells demonstrating a further clear difference in response between breast and endometrial cells.

We have previously shown that OHT is capable of stabilising ER $\alpha$ in Ishikawa cells, and inducing ligandmediated degradation of ER $\beta$ protein, but not ER $\alpha$ (Horner-Glister et al. 2005). This effect was shown to be cell-type specific, since in breast cancer cells, ER $\alpha$ protein is targeted for rapid degradation via the ubiquitin-proteasome pathway in response to $E_{2}$ (Dowsett \& Ashworth 2003). The ubiquitin-like protein neural precursor cell-expressed developmentally down-regulated (NEDD8) is essential for protein processing and cell-cycle progression, and has been linked to ubiquitination of $\mathrm{ER} \alpha$ (Fan et al. 2003) and an intact NEDD8 pathway is essential for ER $\alpha$ ubiquitination and degradation. This gene was significantly down-regulated in our study in response to OHT at $24 \mathrm{~h}$, but not by $\mathrm{E}_{2}$, suggesting that ER degradation could be partly responsible for the differential effects of OHT and $\mathrm{E}_{2}$ in this cell type. VINEXIN $\beta$ (SCAM-1; SH3 containing adaptor molecule); a focal adhesion protein, which regulates the anchorage dependence of ERK2 activation (Suwa et al. 2002) was one of the most down-regulated genes following OHT treatment at $24 \mathrm{~h}$. Phosphorylation controls RAR $\gamma$-mediated transcription by triggering the dissociation of VINEXIN $\beta$ from the focal adhesion plaque (Bour et al. 2005). As a member of the nuclear receptor superfamily, the retinoid receptor shares some homology and characteristics with the ER. Indeed, VINEXIN $\alpha$ binds in vitro to $\mathrm{ER} \alpha$ and $\mathrm{ER} \beta$ and stimulates the ligand-induced transactivation function of these receptors (Tujague et al. 2004). Downregulation of VINEXIN $\beta$ could therefore influence the downstream transcription activity of OHT-associated ER, which presumably involves the recruitment of a different repertoire of nuclear transcription factors, adaptors or co-regulators.

\section{Differential expression of genes in breast MCF-7 cells versus Ishikawa cells}

Gene expression studies in human MCF-7 cells have shown that some genes respond rapidly within $2 \mathrm{~h}$ whilst others are only maximally induced after 24 to $48 \mathrm{~h}$ (Frasor et al. 2003). More recently, meta-analysis of heterogeneous in vitro and in vivo datasets showed a similar response in expression profiles in breast derived T-47D and MCF-7 cells to $\mathrm{E}_{2}$ (Lin et al. 2004). The highest ranked ER direct target genes were NRIPl, GREB1 and $A B C A 3$. As indicated above, in Ishikawa cells at $24 \mathrm{~h}$, GREB1 was up-regulated by $\mathrm{E}_{2}$ and OHT whilst NRIP1 was up-regulated only by $\mathrm{E}_{2}$. There was no significant change in $A B C A 3$ gene expression. While many have used MCF-7 cells to elucidate the role of the ER in response to oestrogen stimulation (Lin et al. 2004, Stossi et al. 2006), the present results suggest these may be confined only to breast cancer cells and not applicable to other oestrogen-responsive tissues, such as the uterus.

\section{Conclusions}

OHT behaves largely as an oestrogen agonist in this cell type, but also displays oestrogen antagonist activity in the presence of $E_{2}$. The data presented strongly suggest that the effect of OHT or $E_{2}$ on the gene expression profile of human uterine epithelial cells is highly diverse and ligand-specific, and does not necessarily mimic that seen in breast cancer cells, supporting the hypothesis that OHT might be capable of influencing the transcriptional response of a specific subset of genes in the uterus.

\section{Acknowledgements}

We would like to thank Emma Horner-Glister, Anthony $\mathrm{H}$ Taylor and Thierry Bailhache for their helpful discussion and review of the manuscript. We also thank Tim Gant and ShuDong Zhang for advice and assistance on microarray and statistical analyses. The authors declare that there is no conflict of interest that would prejudice the impartiality of this scientific work. 


\section{References}

Amant F, Moerman P, Neven P, Timmerman D, Van Limbergen E \& Vergote I 2005 Endometrial cancer. Lancet 366 491-505.

Anzai Y, Holinka CF, Kuramoto H \& Gurpide E 1989 Stimulatory effects of 4-hydroxytamoxifen on proliferation of human endometrial adenocarcinoma cells (Ishikawa line). Cancer Research 49 2362-2365.

Bour G, Plassat JL, Bauer A, Lalevee S \& Rochette-Egly C 2005 Vinexin beta interacts with the non-phosphorylated AF-1 domain of retinoid receptor gamma (RARgamma) and represses RARgamma-mediated transcription. Journal of Biological Chemistry 280 17027-17037.

Bramlett KS \& Burris TP 2003 Target specificity of selective estrogen receptor modulators within human endometrial cancer cells. Journal of Steroid Biochemistry and Molecular Biology 86 27-34.

Cohen I 2004 Endometrial pathologies associated with postmenopausal tamoxifen treatment. Gynecologic Oncology 94 256-266.

Cohen I, Rosen DJ, Shapira J, Cordoba M, Gilboa S, Altaras MM, Yigael D \& Beyth Y 1993 Endometrial changes in postmenopausal women treated with tamoxifen for breast cancer. British Journal of Obstetrics Gynaecology 100 567-570.

Cole MP, Jones CT \& Todd ID 1971 A new anti-oestrogenic agent in late breast cancer. An early clinical appraisal of ICI46474. British Journal of Cancer 25 270-275.

Croxtall JD, Elder MG \& White JO 1990 Hormonal control of proliferation in the lshikawa endometrial adenocarcinoma cell line. Journal of Steroid Biochemistry 35 665-669.

Dardes RC, Schafer JM, Pearce ST, Osipo C, Chen B \& Jordan VC 2002 Regulation of estrogen target genes and growth by selective estrogen-receptor modulators in endometrial cancer cells. Gynecologic Oncology 85 498-506.

Dowsett M \& Ashworth A 2003 New biology of the oestrogen receptor. Lancet 362 260-262.

Fan M, Bigsby RM \& Nephew KP 2003 The NEDD8 pathway is required for proteasome-mediated degradation of human estrogen receptor (ER)-alpha and essential for the antiproliferative activity of ICI 182780 in ERalphapositive breast cancer cells. Molecular Endocrinology 17 356-365.

Fisher B, Costantino JP, Wickerham DL, Redmond CK, Kavanah M, Cronin WM, Vogel V, Robidoux A, Dimitrov N, Atkins J et al. 1998 Tamoxifen for prevention of breast cancer: report of the National Surgical Adjuvant Breast and Bowel Project P-1 Study. Journal of the National Cancer Institute 90 1371-1388.

Frasor J, Danes JM, Komm B, Chang KC, Lyttle CR \& Katzenellenbogen BS 2003 Profiling of estrogen up- and down-regulated gene expression in human breast cancer cells: insights into gene networks and pathways underlying estrogenic control of proliferation and cell phenotype. Endocrinology 144 4562-4574.
Frasor J, Stossi F, Danes JM, Komm B, Lyttle CR \& Katzenellenbogen BS 2004 Selective estrogen receptor modulators: discrimination of agonistic versus antagonistic activities by gene expression profiling in breast cancer cells. Cancer Research 64 1522-1533.

Furr BJA \& Jordan VC 1984 The pharmacology and clinical uses of tamoxifen. Pharmacology and Therapeutics 25 127-205.

Ghosh MG, Thompson DA \& Weigel RJ 2000 PDZK1 and GREB1 are estrogen-regulated genes expressed in hormoneresponsive breast cancer. Cancer Research 60 6367-6375.

Holinka CF, Hata H, Kuramoto H \& Gurpide E 1986 Responses to estradiol in a human endometrial adenocarcinoma cell line (Ishikawa). Journal of Steroid Biochemistry 24 85-89.

Horner-Glister E, Maleki-Dizaji M, Guerin CJ, Johnson SM, Styles J \& White IN 2005 Influence of oestradiol and tamoxifen on oestrogen receptors-alpha and -beta protein degradation and non-genomic signalling pathways in uterine and breast carcinoma cells. Journal of Molecular Endocrinology 35 421-432.

Kasiotis KM, Mendorou C, Haroutounian SA \& Alexis MN 2006 High affinity 17[alpha]-substituted estradiol derivatives: synthesis and evaluation of estrogen receptor agonist activity. Steroids 71 249-255.

Kato S 2001 Estrogen receptor-mediated cross-talk with growth factor signaling pathways. Breast Cancer 8 3-9.

Keeton EK \& Brown M 2005 Cell cycle progression stimulated by tamoxifen-bound estrogen receptor-alpha and promoterspecific effects in breast cancer cells deficient in N-CoR and SMRT. Molecular Endocrinology 19 1543-1554.

Kian TM, Rogatsky I, Tzagarakis-Foster C, Cvoro A, An J, Christy RJ, Yamamoto KR \& Leitman DC 2004 Estradiol and selective estrogen receptor modulators differentially regulate target genes with estrogen receptors alpha and beta. Molecular Biology of the Cell 15 1262-1272.

Klinge CM, Jernigan SC, Mattingly KA, Risinger KE \& Zhang J 2004 Estrogen response element-dependent regulation of transcriptional activation of estrogen receptors alpha and beta by coactivators and corepressors. Journal of Molecular Endocrinology 33 387-410.

Kushner PJ, Agard D, Feng WJ, Lopez G, Schiau A, Uht R, Webb P \& Greene G 2000 Oestrogen receptor function at classical and alternative response elements. Novartis Foundation Symposium 230 20-26.

Lessey BA, Ilesanmi AO, Castelbaum AJ, Yuan L, Somkuti SG, Chwalisz K \& Satyaswaroop PG 1996 Characterization of the functional progesterone receptor in an endometrial adenocarcinoma cell line (Ishikawa): progesterone-induced expression of the alpha1 integrin. Journal of Steroid Biochemistry and Molecular Biology 59 31-39.

Levine RL, Cargile CB, Blazes MS, van Rees B, Kurman RJ \& Ellenson LH 1998 PTEN mutations and microsatellite instability in complex atypical hyperplasia, a precursor lesion to uterine endometrioid carcinoma. Cancer Research 58 3254-3258. 
Lin CY, Strom A, Vega VB, Kong SL, Yeo AL, Thomsen JS, Chan WC, Doray B, Bangarusamy DK, Ramasamy A et al. 2004 Discovery of estrogen receptor alpha target genes and response elements in breast tumor cells. Genome Biology 5 R66.

Littlefield BA, Gurpide E, Markiewicz L, McKinley B \& Hochberg RB 1990 A simple and sensitive microtiter plate estrogen bioassay based on stimulation of alkaline phosphatase in Ishikawa cells: estrogenic action of delta 5 adrenal steroids. Endocrinology 127 2757-2762.

Liu HL, Golder-Novoselsky E, Seto MH, Webster L, McClary J \& Zajchowski DA 1998 The novel estrogenresponsive $\mathrm{B}$-box protein $(E B B P)$ gene is tamoxifenregulated in cells expressing an estrogen receptor DNAbinding domain mutant. Molecular Endocrinology 12 1733-1748.

Lonard DM \& Smith CL 2002 Molecular perspectives on selective estrogen receptor modulators (SERMs): progress in understanding their tissue-specific agonist and antagonist actions. Steroids 67 15-24.

McDonnell DP \& Norris JD 2002 Connections and regulation of the human estrogen receptor. Science 296 1642-1644.

McGonigle KF, Smith DD, Marx HF, Morgan RJ, Vasilev SA, Roy S, Wong PT, Simpson JF \& Wilczynski SP 2006 Uterine effects of tamoxifen: a prospective study. International Journal of Gynecological Cancer 16 814-820.

Monroe DG, Secreto FJ, Subramaniam M, Getz BJ, Khosla S \& Spelsberg TC 2005 Estrogen receptor alpha and beta heterodimers exert unique effects on estrogen- and tamoxifen-dependent gene expression in human U2OS osteosarcoma cells. Molecular Endocrinology 19 1555-1568.

Mutter GL, Baak JP, Fitzgerald JT, Gray R, Neuberg D, Kust GA, Gentleman R, Gullans SR, Wei LJ \& Wilcox M 2001 Global expression changes of constitutive and hormonally regulated genes during endometrial neoplastic transformation. Gynecologic Oncology 83 177-185.

Pedram A, Razandi M, Aitkenhead M, Hughes CC \& Levin ER 2002 Integration of the non-genomic and genomic actions of estrogen. Membrane-initiated signaling by steroid to transcription and cell biology. Journal of Biological Chemistry 277 50768-50775.

Pelzer T, Schumann M, Neumann M, deJager T, Stimpel M, Serfling E \& Neyses L 2000 17beta-estradiol prevents programmed cell death in cardiac myocytes. Biochemical and Biophysical Research Communications 268 192-200.

Pole J, Carmichael P \& Griffin J 2004 Identification of transcriptional biomarkers induced by SERMS in human endometrial cells using multivariate analysis of DNA microarrays. Biomarkers 9 447-460.

Pole JC, Gold LI, Orton T, Huby R \& Carmichael PL 2005 Gene expression changes induced by estrogen and selective estrogen receptor modulators in primarycultured human endometrial cells: signals that distinguish the human carcinogen tamoxifen. Toxicology 206 91-109.
Prasad M, Wang H, Douglas W, Barakat RR \& Ellenson LH 2005 Molecular genetic characterization of tamoxifenassociated endometrial cancer. Gynecologic Oncology 96 25-31.

Rae JM, Johnson MD, Scheys JO, Cordero KE, Larios JM \& Lippman ME 2005 GREB 1 is a critical regulator of hormone dependent breast cancer growth. Breast Cancer Research and Treatment 92 141-149.

Rau SW, Dubal DB, Bottner M, Gerhold LM \& Wise PM 2003 Estradiol attenuates programmed cell death after stroke-like injury. Journal of Neuroscience 23 11420-11426.

Robertson JA, Farnell Y, Lindahl LS \& Ing NH 2002 Estradiol up-regulates estrogen receptor messenger ribonucleic acid in endometrial carcinoma (Ishikawa) cells by stabilizing the message. Journal of Molecular Endocrinology 29 125-135.

Shah YM, Basrur V \& Rowan BG 2004 Selective estrogen receptor modulator regulated proteins in endometrial cancer cells. Molecular and Cellular Endocrinology 219 127-139.

Shah YM, Al Dhaheri M, Dong Y, Ip C, Jones FE \& Rowan BG 2005 Selenium disrupts estrogen receptor (alpha) signaling and potentiates tamoxifen antagonism in endometrial cancer cells and tamoxifen-resistant breast cancer cells. Molecular Cancer Therapy 4 1239-1249.

Shang Y 2006 Molecular mechanisms of oestrogen and SERMs in endometrial carcinogenesis. Nature Reviews. Cancer 6 360-368.

Shang Y \& Brown M 2002 Molecular determinants for the tissue specificity of SERMs. Science 295 2465-2468.

Smith CL, Nawaz Z \& O'Malley BW 1997 Coactivator and corepressor regulation of the agonist/antagonist activity of the mixed antiestrogen, 4-hydroxytamoxifen. Molecular Endocrinology 11 657-666.

Song RX \& Santen RJ 2006 Membrane initiated estrogen signaling in breast cancer. Biology of Reproduction $\mathbf{7 5}$ 9-16.

Song RX, McPherson RA, Adam L, Bao Y, Shupnik M, Kumar R \& Santen RJ 2002 Linkage of rapid estrogen action to MAPK activation by ERalpha-Shc association and Shc pathway activation. Molecular Endocrinology 16 116-127.

Stossi F, Barnett DH, Frasor J, Komm B, Lyttle CR \& Katzenellenbogen BS 2004 Transcriptional profiling of estrogen-regulated gene expression via estrogen receptor (ER) alpha or ERbeta in human osteosarcoma cells: distinct and common target genes for these receptors. Endocrinology 145 3473-3486.

Stossi F, Likhite VS, Katzenellenbogen JA \& Katzenellenbogen BS 2006 Estrogen-occupied estrogen receptor represses cyclin $G 2$ gene expression and recruits a repressor complex at the cyclin $\mathrm{G} 2$ promoter. Journal of Biological Chemistry 281 16272-16278.

Suwa A, Mitsushima M, Ito T, Akamatsu M, Ueda K, Amachi T \& Kioka N 2002 Vinexin beta regulates the 
anchorage dependence of ERK2 activation stimulated by epidermal growth factor. Journal of Biological Chemistry 277 13053-13058.

Tang S, Han H \& Bajic VB 2004 ERGDB: estrogen responsive genes database. Nucleic Acids Research 32 D533-D536.

Taylor AH, al Azzawi F, Pringle JH \& Bell SC 2002 Inhibition of endometrial carcinoma cell growth using antisense estrogen receptor oligodeoxyribonucleotides. Anticancer Research 22 3993-4003.

Tujague M, Thomsen JS, Mizuki K, Sadek CM \& Gustafsson JA 2004 The focal adhesion protein vinexin alpha regulates the phosphorylation and activity of estrogen receptor alpha. Journal of Biological Chemistry 279 9255-9263.

Vanparys C, Maras M, Lenjou M, Robbens J, Van Bockstaele D, Blust R \& De Coen W 2006 Flow cytometric analysis allows for rapid screening of estrogenicity in MCF7 breast cancer cells. Toxicology In Vitro 20 1238-1248.

Vivacqua A, Bonofiglio D, Recchia AG, Musti AM, Picard D, Ando S \& Maggiolini M 2006 The G protein-coupled receptor GPR30 mediates the proliferative effects induced by 17 beta-estradiol and hydroxytamoxifen in endometrial cancer cells. Molecular Endocrinology 20 631-646.
Wakeling AE 2000 Similarities and distinctions in the mode of action of different classes of antioestrogens. EndocrineRelated Cancer 7 17-28.

Ward HW 1973 Anti-oestrogen therapy for breast cancer: a trial of tamoxifen at two dose levels. BMJ 1 13-14.

Watanabe T, Inoue S, Ogawa S, Ishii Y, Hiroi H, Ikeda K, Orimo A \& Muramatsu M 1997 Agonistic effect of tamoxifen is dependent on cell type, ERE-promoter context, and estrogen receptor subtype: functional difference between estrogen receptors alpha and beta. Biochemical and Biophysical Research Communications 236 140-145.

White INH 2001 Anti-oestrogenic drugs and endometrial cancers. Toxicology Letters 120 21-29.

Wu H, Chen Y, Liang J, Shi B, Wu G, Zhang Y, Wang D, Li R, Yi X, Zhang H et al. 2005 Hypomethylation-linked activation of PAX2 mediates tamoxifen-stimulated endometrial carcinogenesis. Nature 438 981-987.

Zhang SD \& Gant TW 2004 A statistical framework for the design of microarray experiments and effective detection of differential gene expression. Bioinformatics 20 2821-2828. 